\author{
Volodymyr Skorokhoda
}

\title{
MATRIX POLYMERIZATION OF 2-HYDROXYETHYLMETHACRYLATE IN THE PRESENCE OF POLYVINYLPYRROLIDONE IN PERMANENT MAGNETIC FIELD
}

\author{
Lviv Polytechnic National University \\ 12 S. Bandery str., 79013 Lviv, Ukraine \\ vskorohoda@yahoo.com
}

Received: January 15, 2010 / Accepted: April 04, 2010

(C) Skorokhoda V., 2010

\begin{abstract}
The influence of a constant magnetic field on the polymerization kinetics and structural parameters of a hydrogel network on the basis of 2-hydroxyethylmethacrylate and polyvinylpyrrolidone compositions has been investigated. It has been shown that the magnetic field activates matrix polymerization of such compositions and assists in structure formation of copolymers with minor density. The efficiency of the developed polymeric materials used for production of ultrathin contact lenses has been confirmed.
\end{abstract}

Keywords: polyvinylpyrrolidone, 2-hydroxyethylmethacrylate, magnetic field, contact lenses, seldomcrosslinked copolymers.

\section{Introduction}

The seldom-crosslinked copolymers of polyvinylpyrrolidone (PVP) / 2-hydroxyethylmethacrylate (HEMA) are successfully applied in biomedical practice, including the manufacture of endoprostheses, medicative and correcting contact lenses, implants, dental compositions, etc. [1]. They are obtained, basically, via thermo-, photo- and radiation polymerization in the presence of initiators or without them. The possibility of activation of such polymerization system resulting in the complex formation with a charge transfer in the system of monomer - polymeric matrix - protonic-donor solvent has been shown through investigations carried out at the Department of Chemical Technology and Plastics Processing of Lviv Polytechnic National University $[2,3]$.

It is foreseen that reactivity of polymeric matrix under polymerization conditions can be strengthened by orientational, diffusive and solvation effects generated by external energy fields, namely by a constant magnetic one. At the same time the polymerization processes under the magnetic field influence are studied insufficiently; therefore researches in this direction provide deepening of theoretical conceptions about polymer formation as well as enhancement of new polymers synthesis and modification of existing ones. Thus, the mentioned researches will allow to enrich the existing practice by new non-traditional syntheses of perspective materials based on copolymers.

Therefore, the aim of this work is to investigate the influence of a constant magnetic field on polymerization kinetics, structure formation and the properties of HEMA / PVP copolymers.

\section{Experimental}

The following materials were used for polymerization: HEMA purified by vacuum distillation (residual pressure $130 \mathrm{~N} / \mathrm{m}^{2}, T_{\text {boil }}=351 \mathrm{~K}$ ), ethylene glycol dimethacrylate (DMEG) (residual pressure $400 \mathrm{~N} / \mathrm{m}^{2}$, $T_{\text {boil }}=343 \mathrm{~K}$ ) and PVP of high purity with a molecular mass $28 \cdot 10^{3}$. Benzoyl peroxide (BP) was recrystallizated twice from methanol and used as a polymerization initiator.

The constant magnetic field was produced using powder magnets based on ferrum-neodymium-boron isotope $\left(\mathrm{Fe}_{14} \mathrm{Nd}_{2} \mathrm{~B}\right)$ which are characterised by the following properties: the residual magnetic induction $B_{r}=1.15 \mathrm{~T}$; the coercive force by magnetization $H_{c}=$ $=400 \mathrm{kA} / \mathrm{m}$; the maximum magnetic energy $(B H / 2)_{\text {max }}=$ $=240 \mathrm{~kJ} / \mathrm{m}^{3}$. Magnets have the form of solid disks with the diameter of $97 \mathrm{~mm}$ and thickness of $20 \mathrm{~mm}$ which are enveloped by the magneto-conductor with one mobile pole. The voltage of magnetic field is regulated by a free distance between disks. The magnets have been produced by the assistance professor S. Yaremkevych at the Department of Material Sciences and Applied Physics. 
The molecular mass of a chain section between neighboring crosslinking nodes is calculated by the following formula [4]:

$$
M_{n}=\frac{L^{5} \rho_{p} V_{s}}{0.5-\mu}
$$

where $L$ - coefficient of linear swelling; $\rho_{p}$ - polymer density, $\mathrm{kg} / \mathrm{m}^{3} ; V_{s}-$ molar volume of the solvent, $\mathrm{m}^{3} \cdot \mathrm{kg}^{-1} \cdot \mathrm{mol}^{-1} ; \mu$ - parameter of polymer-liquid interaction

$$
\mu=0.5-\frac{V_{s} \sigma_{\infty} L^{4}}{R T\left(\lambda^{2}-\lambda^{-1}\right)}
$$

$\sigma_{\infty}-$ equilibrium tension, $\mathrm{kg} / \mathrm{m}^{2}$

$$
\lambda=1+\varepsilon, \quad 0<\varepsilon<0.3
$$

$\varepsilon-$ equilibrium elongation

The polymerization kinetics was investigated using a dilatometric analysis [5]. Copolymers composition and structural parameters were investigated using the procedures described in [6] and permeability of polymers for water and $\mathrm{NaCl}$ - using the procedure offered by Karelin [7].

\section{Results and Discussion}

HEMA polymerization was studied in the presence of PVP with the ratio HEMA:PVP = (10:0) $-(7: 3)$ mass parts in the range of magnetic field voltage $H=0-310 \mathrm{kA} / \mathrm{m}$ and temperatures range of 303-333 K. The influence of the magnetic field on kinetics of HEMA homopolymerization was studied previously with the ratio monomer : initiator $=10: 0.03$ mass parts at $313 \mathrm{~K}$. It is determined, that HEMA homopolymerization in a magnetic field, as well as without it proceeds with an identical rate (Fig. 1, curve 5 and 5'), i.e. it is possible to ascertain that the magnetic field does not affect HEMA homopolymerization.

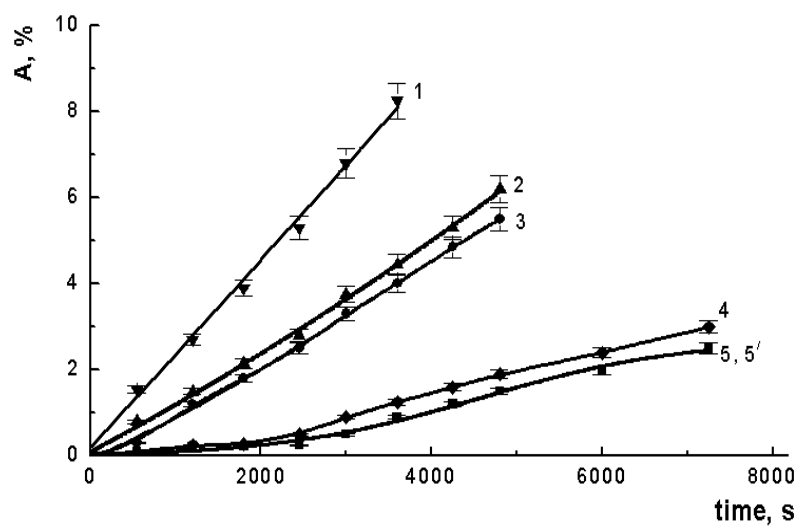

Fig. 1. Initial polymer dependence on the composition content: HEMA:PVP ratio (mass parts): 7:3 (1); 8:2 (2); 9:1 (3,

4) and 10:0 (5, 5'). PVP molecular mass is 28000; magnetic field voltage is $(\mathrm{kA} / \mathrm{m}): 310(1-3,5)$ and $0\left(4,5^{\prime}\right) ; T=313 \mathrm{~K}$;

$$
[\mathrm{PB}]=0.3 \%
$$

At the same time, the magnetic field accelerates the process in case of polymerization of PVP-containing compositions with peroxide and also without it. Moreover, as well as in case of thermoinitiated polymerization [3], the rate increases proportionally to the increase of polymeric matrix quantity in the composition (Fig. 1).

For the phenomena which are observed, it is possible to give the most probable explanation, proceeding from previously determined mechanism of methacrylates matrix polymerization in the presence of PVP. The process evidently [6] is accompanied by monomer molecules salvation over PVP-matrix with the complex formation and charge-transfer between PVP tertiary nitrogen and monomer double bond.

To confirm and amend the structure of PVP/HEMA complex quantum-mechanical calculations have been done using Chem 3D programme taking into account covalent, torsion and electrostatic interactions. PVP, HEMA and their complex structural formulas are obtained; interatomic distances, atom charges and energetic parameters are determined. The molecules and complex firm conformation are determined by means of minimum values of their total energy using energy minimization and quantum-dynamic processing.
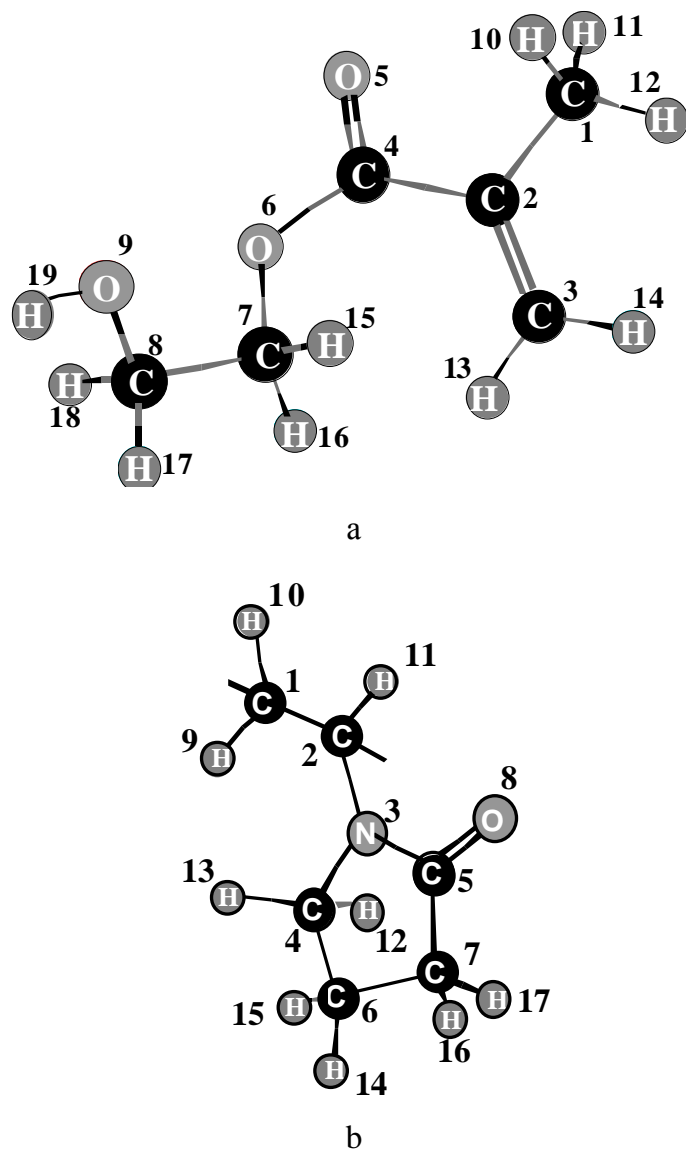

Fig. 2. Models of HEMA molecule (a) and PVP chain (b) 
According to the calculations, PVP conformation is characterized by a spiral structure, where lactam cycles are directed radially from the spiral axis. HEMA molecule and fragment of PVP chain are represented in Fig. 2.

Energetic parameters of calculated structures are represented in Table 1.

To investigate the effect of complex composition on its structure and energetic parameters the complexes with the ratio PVP : HEMA $=(5: 1)-(1: 2)$ based $\mathrm{mol} / \mathrm{mol}$ are modelled. In all cases the maximum polarization and minimum intermolecular distance are observed between PVP tertiary nitrogen and $\alpha$-carbon of monomer double bond (Table 2). The complex with PVP : HEMA = 1:1 based $\mathrm{mol} / \mathrm{mol}$ is characterized by the least total energy and has the firm conformation.
HEMA salvation over PVP with the complex formation and charge transfer redistributes electronic density and weakens $\mathrm{C}=\mathrm{C}$ bond, it creates favourable kinetic conditions for initiation and growth of polymeric chains, when diffusive-limited factors are reduced to minimum. The dissociation of double bond in monomer molecules is facilitated and the polymerization rate increases because of complexation. On the other hand, it is known [8] that orientation in the magnetic field is caused, mainly, by anisotropy of molecules diamagnetic susceptibility. The single bond has the greatest diamagnetic susceptibility when the field is directed along a bond axis, therefore the molecule is orientated perpendicularly to a field; and double bond orients the molecule in parallel to the magnetic field, when the field is directed perpendicularly to the bond axis.

HEMA and PVP structural and energetic parameters

\begin{tabular}{|c|c|c|c|c|c|}
\hline Modelling object & $E_{\text {elong., }} \mathrm{kJ} / \mathrm{mol}$ & $E_{\text {tors }}, \mathrm{kJ} / \mathrm{mol}$ & $E_{\text {tot., }} \mathrm{kJ} / \mathrm{mol}$ & Distance between atoms, $\AA$ & Atomic charge, $\mathrm{eV}$ \\
\hline HEMA & 3.2 & 19.9 & 66.1 & $\begin{array}{l}\mathrm{C}_{2}=\mathrm{C}_{3}=1.347 \\
\mathrm{C}_{4}=\mathrm{O}_{5}=1.229\end{array}$ & $\begin{array}{c}\mathrm{C}_{2}(0.0676) \\
\mathrm{C}_{1}(-0.1292)\end{array}$ \\
\hline PVP* & 13.3 & 169.5 & 228.4 & $\begin{array}{l}\mathrm{C}_{2} *-\mathrm{N}_{3} *=1.462 \\
\mathrm{C}_{5}^{*}-\mathrm{O}_{8} *=1.207 \\
\mathrm{~N}_{3} *-\mathrm{C}_{5} *=1.363\end{array}$ & $\begin{array}{c}\mathrm{N}_{3} *(0.3506) \\
\mathrm{O}_{8} *(-0.8221) \\
\mathrm{C}_{2} *(0.0665)\end{array}$ \\
\hline
\end{tabular}

Structural parameters of HEMA/PVP complex

Table 2

\begin{tabular}{|c|c|l|c|}
\hline \multirow{2}{*}{$\begin{array}{c}\text { Modelling } \\
\text { object }\end{array}$} & $E_{\text {tot }} \mathrm{kJ} / \mathrm{mol}$ & \multicolumn{2}{|c|}{ Distance between atoms, $\AA$} \\
\cline { 3 - 4 } & & \multicolumn{1}{|c|}{ Intramolecular } & \multicolumn{1}{c|}{ Intermolecular } \\
\hline \multirow{3}{*}{ HEMA+PVP* } & \multirow{2}{*}{172.0} & $\begin{array}{l}\mathrm{C}_{2}=\mathrm{C}_{3}=1.447 ; \mathrm{C}_{4}=\mathrm{O}_{5}=1.221 ; \\
\mathrm{C}_{2}{ }^{*}-\mathrm{N}_{3}{ }^{*}=1.460 ; \mathrm{C}_{5}{ }^{*}-\mathrm{O}_{8}{ }^{*}=1.205 ; \\
\mathrm{N}_{3}{ }^{*}-\mathrm{C}_{5}{ }^{*}=1.359\end{array}$ & $\begin{array}{l}\mathrm{C}_{2}-\mathrm{N}_{3}{ }^{*}=5.403 ; \mathrm{C}_{3}-\mathrm{N}_{3}{ }^{*}=6.396 ; \\
\mathrm{C}_{2}-\mathrm{O}_{8}{ }^{*}=3.684 ; \mathrm{C}_{3}-\mathrm{O}_{8}{ }^{*}=4.406 ; \\
\mathrm{O}_{5}-\mathrm{N}_{3}{ }^{*}=7.600\end{array}$ \\
\hline
\end{tabular}

In work [8] the assumption is expressed, that since the peptide bond partially has a character of the double bond due to the presence of two resonance structures, this bond should have anisotropy of a diamagnetic susceptibility. Thus, the peptide bond anisotropy has the same sign and almost the same value as the double bond. Considering the abovementioned and similarity of the peptide bond with the bond in the PVP macromolecule, it is possible to foresee that the plane of the single bond in PVP macromolecule aspires to be orientated perpendicularly to the magnetic field, and the bond which connects a cycle with the main chain - in parallel (as well as a plane of double bond in $\mathrm{C}=\mathrm{C}$ monomer) (Fig. 3).

Therefore it is possible to assume that aggregation of monomer molecules near the polymeric matrix is weakened owing to such magnetic field orientation. This fact facilitates, in turn, the access of monomer molecules fragments to the active groups of PVP macromolecules strengthening complexation which is the factor of polymerization acceleration [9]. As a result of the oriented distribution of macromolecules the mobility of formed associates decreases, the better kinetic conditions of chain growth are created and the starting conditions for the structure formation of (co)polymers with the arranged distribution of macrochains are also determined.

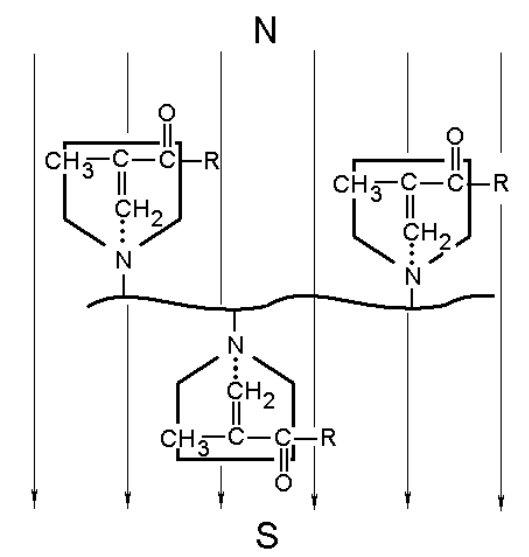

Fig. 3. The components orientation of monomer-polymer composition in the magnetic field 
During polymerization in the solution the important affecting factor on the polymerization rate is the nature of solvent and its properties among which dielectric permeability $(\varepsilon)$ is a determinant value (Table 3 ). Researches have shown that polymerization rate of the HEMA / PVP compositions decreases in a row: water $(\varepsilon=78.3)>$ dimethyl sulfoxide (DMSO) $(\varepsilon=46.6)>$ ethylene glycol (EG) $(\varepsilon=37.7)>$ butanol $(\varepsilon=17.7)$.

On the basis of experimental investigations the basic kinetic parameters (rate constants, reaction orders, activation energies) of polymerization reactions are calculated for HEMA : PVP $=9: 1$ mass parts in MAGNETIC FIELD. The effective activation energy of the process in DMSO is $46 \pm 2$, in water $-39 \pm 2 \mathrm{~kJ} / \mathrm{mol}$. These values are considerably lower in comparison with polymerization of such systems without the magnetic field (67 and $57 \mathrm{~kJ} / \mathrm{mol}$ correspondingly [9]). The received values testify to an active role of solvents in the polymerization process in the magnetic field which changes depending on their dielectric permeability.
At the same time it has been established that the magnetic field perceptibly influences the crosslinking during HEMA homopolymerization. In the magnetic field a crosslinking density decreases in a greater degree than at polymerization of compositions with PVP (Table 4), though, as it was shown above, the magnetic field practically does not affect the HEMA homopolymerization kinetics.

The received dependences are in a good agreement with the offered above orientation scheme of monomerpolymeric composition components in the magnetic field and are caused by its influence on monomer molecules aggregation as a result of the polarising and orientational phenomena. Since planes of $\mathrm{C}=\mathrm{C}$ double bonds of both HEMA, and ethylene glycol dimethacrylate (DMEG), which is responsible for the formation of the structural network at HEMA polymerization, are orientated in parallel to an external magnetic field, the best kinetic conditions of chain growth in the reaction of HEMA with DMEG binary copolymerization are created. Therefore the part of DMEG

Effect of magnetic field voltage $(H)$ and solvent dielectric permeability $(\varepsilon)$ on polymerization rate $\left(V_{p}\right)$ of compositions containing $\operatorname{PVP}(T=313 \mathrm{~K})$

\begin{tabular}{|l|c|c|c|}
\hline \multicolumn{1}{|c|}{ Composition content $*$} & $H, \kappa \mathrm{A} / \mathrm{m}$ & $\varepsilon$ & $V_{p}, \mathrm{~mol}^{*} \cdot \mathrm{dm}^{-3} \cdot \mathrm{s}^{-1}$ \\
\hline \multirow{2}{*}{ HEMA:PVP } & 0 & & $4.7 \cdot 10^{-5}$ \\
\cline { 2 - 2 } & 310 & & $11.4 \cdot 10^{-5}$ \\
\hline HEMA:PVP: $\mathrm{H}_{2} \mathrm{O}$ & 310 & 78.3 & $8.8 \cdot 10^{-6}$ \\
\hline HEMA:PVP:DMSO & 310 & 46.6 & $5.2 \cdot 10^{-6}$ \\
\hline HEMA:PVP:EG & 310 & 37.7 & $2.3 \cdot 10^{-6}$ \\
\hline HEMA:PVP:butanol & 310 & 17.7 & $1.3 \cdot 10^{-6}$ \\
\hline
\end{tabular}

* HEMA : PVP : solvent : PB = 9 : $1: 10: 0.02$ mass parts

Structural characteristics of the net and properties of copolymers synthesized in the magnetic field $(T=313 \mathrm{~K},[\mathrm{~PB}]=0.3$ mas \% $)$

\begin{tabular}{|c|c|c|c|c|c|c|}
\hline $\begin{array}{c}\text { HEMA : PVP, } \\
\text { mass parts }\end{array}$ & $H, \mathrm{KA} / \mathrm{m}$ & $\begin{array}{c}M_{n}, \\
\mathrm{~kg} \cdot \mathrm{mol}^{-1}\end{array}$ & $\begin{array}{c}\mathrm{v}=10^{2} / M_{n}, \\
\mathrm{~mol} \cdot \mathrm{kg}^{-1}\end{array}$ & $\begin{array}{c}D_{\mathrm{NaCl}} \cdot 10^{12}, \\
\mathrm{~m}^{2} / \mathrm{s}\end{array}$ & $\begin{array}{c}F^{*}, \\
\mathrm{MPa}\end{array}$ & $\begin{array}{c}T_{\mathrm{V}}^{*}, \\
\mathrm{~K}\end{array}$ \\
\hline \multirow{2}{*}{$10: 0$} & 0 & $6.2 \pm 1.0$ & 16.1 & 0.83 & $200 \pm 5$ & $357 \pm 1$ \\
& 310 & $17.3 \pm 2.0$ & 5.8 & 0.94 & $278 \pm 5$ & $378 \pm 2$ \\
\hline \multirow{2}{*}{$9: 1$} & 0 & $7.0 \pm 1.0$ & 14.3 & 0.89 & $219 \pm 5$ & $365 \pm 1$ \\
& 310 & $9.5 \pm 1.0$ & 10.5 & 1.00 & $258 \pm 5$ & $377 \pm 1$ \\
\hline \multirow{2}{*}{$8: 2$} & 0 & $11.3 \pm 1.0$ & 8.9 & 2.11 & $288 \pm 5$ & $369 \pm 1$ \\
& 310 & $11.9 \pm 1.5$ & 8.4 & 2.61 & $333 \pm 8$ & $383 \pm 2$ \\
\hline \multirow{2}{*}{$7: 3$} & 0 & $11.7 \pm 1.5$ & 8.6 & 3.49 & $296 \pm 7$ & $372 \pm 1$ \\
& 310 & $14.6 \pm 1.5$ & 6.9 & 4.17 & $340 \pm 8$ & $385 \pm 2$ \\
\hline
\end{tabular}

Notes: $M_{n}-$ molecular mass of the net fragment; - crosslinking density; $D_{\mathrm{NaCl}}$ - diffusion coefficient of $\mathrm{NaCl}$ through the hydrogel; $F$ - surface hardness; $T \mathrm{v}$ - heat resistance by Vicata.

* properties in the solid state, others - in the equilibrium swelling state. 
decreases in the crosslinking reaction and the copolymer is formed with a smaller crosslinking density (with a higher value of $M_{n}$ ) and the best operational properties (Table 4).

Interrelation between the obtained conditions, the structure and the basic operational properties of synthesised copolymers in the magnetic field are ascertained for the purpose of engineering development of copolymer synthesis and obtaining of medical products on their basis, including contact lenses. It is established that lapping of the magnetic field (the voltage of $310 \mathrm{kA} / \mathrm{m}$ ) on the composition raises sorption ability and permeability of copolymers for water and the low-molecular substances dissolved in it by 10-15\% (Table 4). It is one of the basic characteristics for estimation of duration and comfort of ophthalmic lenses application. The increase of surface hardness of copolymers synthesised in the magnetic field (which determines their suitability to mechanical treatment during products manufacturing), in comparison with the samples obtained by thermopolymerization (from 200 to $278 \mathrm{MPa}$ for homopolymer and from 210-296 to 231-
$340 \mathrm{MPa}$ for copolymers depending upon their composition), is determined by the fact that the polymer with more arranged and less defective structure is formed under the magnetic field conditions. Researches confirm the possibility of hydrophilic polymers obtaining in the constant magnetic field. They have the increased physicomechanical properties and may be processed into products by the mechanical treatment method.

The experimental results of the magnetic field influence on the formation of copolymers structure have been used for the technological implementation of "Glipox" hydrophilic polymeric material for ultrathin contact lenses and the accommodative crystalline lenses. "Glipox" properties are given in Table 5.

The lenses successfully passed the industrial and toxicological tests. They are stable to the action of detergents and disinfectants; endure sterilization in water without changing optical and physico-mechanical properties. The lenses are produced with a refraction from -25 to $+18 \mathrm{D}$, their thickness in the centre is from 0.04 to $0.10 \mathrm{~mm}$ depending on their refraction.

\section{Technical characteristics of "Glipox" contact lenses in the equilibrium swelling state}

\section{Table 5}

\begin{tabular}{|l|c|}
\hline \multicolumn{1}{|c|}{ Technical characteristics } & Value \\
\hline Lenses minimal thickness in the centre, $\mathrm{mm}$ & 0.04 \\
\hline Tensile strength, $\mathrm{MPa}$ & 6.9 \\
\hline Elasticity, \% & 69 \\
\hline Water content, \% & 38 \\
\hline Light permeability, \% & 96 \\
\hline NaCl permeability ${ }^{*}, \mathrm{~mol}^{*} \mathrm{~m}^{-2} \cdot \mathrm{h}^{-1}$ & 264 \\
\hline Water permeability ${ }^{*} \mathrm{~m}^{3} \cdot \mathrm{m}^{-2} \cdot \mathrm{h}^{-1}$ & $76.3 \cdot 10^{-3}$ \\
\hline
\end{tabular}

* for minimal thickness

\section{Conclusions}

The activated influence of constant magnetic field on the polymerization kinetics of HEMA/PVP compositions, as well as forming of copolymers with a more arranged structure, smaller crosslinking density and the best operational properties have been investigated. It has been used for technological implementation of the polymeric material obtained for ultrathin contact lenses.

\section{References}

[1] Suberlyak O., Skorokhoda V. and Gavlo I. : [in:] Mazurkiewicz S. (Ed.), Plastics in Machine Design. Krakow, Poland 1997.
[2] Suberlyak O., Skorokhoda V. and Gritsenko O.: Voprosy Khim. i Khim, Techn., 2000, 1, 236.

[3] Skorokhoda V., Semenyuk N. and Suberlyak O.: Polymernyi Zh., 2004, 2, 86.

[4] Shwarts A. and Grigorovskaya V.: Colloid. Zh., 1985, 1, 30.

[5] Yacymmirskiy K.: Kineticheskye Metody Analyza. Khimiya, Moskwa 1972.

[6] Suberlyak O. and Skorokhoda V.: [in:] Koszkul J. (Ed.), Materialy Polimerowe i ich Przetworstwo. Czestohowa, 2004. [7] Dubyaga V., Perepechkin L. and Katalevskiy E.: Polymernye Membrany. Khimiya, Moskwa 1981.

[8] Ivanov V.: Vysokomol. Soed., 1991, 9, 1811.

[9] Suberlyak O., Skorokhoda V. and Melnyk Yu.: Naukovi Zapysky Nats. Ukr. Kievo-Mogilyansk. Acad., 2007, 66, 33. 
МАТРИЧНАПОЛІМЕРИЗАЦЯ

2-ГЦДРОКСІЕТИЛМЕТАКРИЛАТУ У ПРИСУТНОСТІ ПОЛІВІНІЛПІРОЛДОНУ УПОСТІЙНОМУ МАГНІТНОМУ ПОЛІ

Анотація. Досліджено вплив постійного магнітного поля на кінетику полімеризації та структурні параметри сітки гідрогелів на основі композицій 2-гідроксіетилметакрилату з полівінілпіролідоном. Виявлено, щзо магнітне поле активує матричну полімеризачію таких композичій і сприяє формуванню структури (ко)полімерів з меншою густотою сітки. Підтверджена ефективність використання розроблених полімерних матеріалів для виробництва ультратонких контактних лінз.

Ключові слова: полівінілпіролідон, 2-гідроксіетилметакрилат, магнітне поле, контактні лінзи, рідкоструктуровані (ко)полімери. 